\title{
A FITNESZTRENDEK ÉS ÚJ TÍPUSÚ MOZGÁSFORMÁK TÁRSADALMI ÉS GAZDASÁGI ASPEKTUSAI
}

Müller Anetta - Bácsné Bába Éva - Gabnai Zoltán - Pfau Christa - Pető Károly

\section{Összefoglalás}

A fitneszipar társadalmi-gazdasági jelentösége mára megkérdöjelezhetetlenné vált, melyet egyre növekvö méretei és piaci részesedése is jól bizonyitanak. Az egészséges életmód térnyerése mellett növekszik a kereslet a különféle szabadidös tevékenységek iránt. Az európai egészség-és fitneszpiac 2017-ben és 2018-ban is növekedett, melyet mind a fitneszklubok számának, mind a tagok számának és azok költéshajlandóságának növekedése eredményezett. Kutatásunkban az Észak-alföldi régióban müködö fitnesztermek körében mélyinterjús kutatást végeztünk $(N=33)$. Elemeztük, hogy a régióban müködö fitnesztermek szolgáltatásai hogyan viszonyulnak napjaink nemzetközi fitnesz trendjeihez. Arra kerestük a választ, hogy a szolgáltatók a sportkinálatukban hogyan jelenitik meg a fogyasztói trendeket. Az eredmények azt mutatják, hogy azok a különbözö edzésmódszerek, mozgásformák és funkcionális tréning gyakorlatok jelennek meg a szolgáltatók népszerü kinálatában, melyek leginkább alkalmasak arra, hogy a fogyasztók teljesitöképességét és fittségi szintjét növeljék.

Kulcsszavak: fitnesz, fogyasztói trend, szabadidösport, mozgásformák, sportkinálat, fizikai aktivitás

JEL: L83 


\title{
SOCIAL AND ECONOMIC ASPECTS OF FITNESS TRENDS AND NEW TYPES OF EXERCISES
}

\begin{abstract}
The socio-economic importance of fitness industry has become unquestionable, which is evidenced by its increasing size and market share. With the rise of a healthy lifestyle, demand for various leisure activities is increasing. Besides the spread of healthy lifestyle, there is growing demand for various leisure activities as well. The European health and fitness market continued to grow in 2017 and 2018 as a result of the increasing number of fitness clubs, club members and their willingness to spend. In our research, we conducted in-depth interviews with gyms operating in the Northern Great Plain Region (N=33). We analyzed how the fitness facilities relate to today's international fitness trends in the region. We sought an answer on how service providers display consumer trends in their sports services supply. The results show that those training methods and functional training practices appear in the supply of service providers, which are most suitable to increase consumers' performance and fitness level.
\end{abstract}

Keywords: fitness, consumer trend, leisure sport, exercise, sports supply, physical activity JEL: L83 


\section{Bevezetés}

Napjainkban a szabadidősport emberi alapszükségletté vált, mely mozgásszegény, ülő életmódunk miatt nélkülözhetetlen ahhoz, hogy az egészségünket és jó közérzetünket megőrizzük (Borbély-Müller, 2008). Az egészségtudatos magatartás terjedése a fitnesztrendek mellett más egészséggel kapcsolatos szolgáltatások (pl. turizmus, rekreáció, sport, élelmiszerfogyasztás, stb.) keresletét és fogyasztói trendjeit is befolyásolja (Fenyves et al., 2014; Fenyves et al., 2016; Lenténé et al., 2018; Pucsok et al., 2018). A trendek, melyek az éppen aktuális fogyasztói szokásokat mutatják, állandóan változnak. A szabadidősportban a fogyasztók igényeinek változása, formálódása miatt a mozgásformák és edzésmódszerek is folyamatosan változnak, igazodnak a társadalmi elvárásokhoz, egyéni igényekhez (Müller, 2009). A sport területét többféle trend befolyásolja, melyből áttekintjük azokat a legfontosabb irányvonalakat, melyek a kutatásunk szempontjából relevánsak és megjelennek a hazai és nemzetközi fitnesztrendekben is.

Számos országban öregedő népességgel találkozhatunk (Simonovits, 2003; Suti, 2009), és az átlagéletkor kitolódásával azt tapasztalhatjuk, hogy a szenior korosztály tábora egyre népesebbé válik. Ennek a korosztálynak egy része egészségtudatos, akik igénylik az aktivitást szabadidejükben. Ez lehet szabadidős sport is, melynek célja leginkább az öregedés tüneteinek csökkentése, az egészség megőrzése vagy az állapotuk javítása. Természetesen a közösség, a szórakozás szintén fontos motivációként jelenik meg a szabadidős tevékenységek, így a sportmozgások választásánál. Mivel sok országban a teljes népességen belül arányaiban csökken a fiatalok száma, így a szabadidősport-szolgáltatók felismerték az idősebb korosztály célcsoportjában rejlő lehetőségeket: amennyiben ennek a célcsoportnak is kínálnak szabadidős sportprogramokat, úgy a célcsoport bővítésével forgalombővülést tudnak realizálni. Az időseknek azonban eltérő a motivációja, illetve igénye a fiatalabb generációhoz képest. Simon et al. (2018) alapján a szenior korosztály számára fontosak a „life-time” sportok, a természetben űzhető sportok, a közösségi programok, a nyújtó-lazító gimnasztika és az egyensúlyfejlesztő programok is. Az idősek körében egyre nő a biztonság, a minőség és a kényelem iránti igény is, melyeket a programkínálat kialakításakor figyelembe kell venni.

Az elhízás, a túlsúly világméreteket ölt napjainkban és hazánkon kívül a fejlődő és fejlett országok túlnyomó része küzd mind a felnőttkori, mind a gyermekkori elhízás ellen (Ding et al., 2016). A fitnesz területén így egyre népszerűbbé válnak azok a sportprogramok (ciklikus-sportok) és edzésmódszerek (HIIT, vagyis magas intenzitású intervallum edzés), melyek a testsúlycsökkentést, az alakformálást és a testzsírszázalék csökkentését célozzák meg. 


\section{Munkahelyi egészség programok}

Számos kutatás bizonyítja, hogy az inaktivitásnak komoly nemzetgazdasági vonatkozásai, terhei és költségei vannak (Ács et al., 2011; Gabnai et al., 2019). Azok a munkavállalók, akik rendszeresen sportolnak, egészségesebbek és nő a teherbíró-képességük is. Mindez a vállalatok számára többletprofitot eredményez, ugyanis ezáltal csökken a munkahelyről történő távolmaradás gyakorisága, a balesetek száma, valamint nő a munka-termelékenység. Így a munkahelyi egészségfejlesztési programokban dominánsan megjelennek a munkavállalókat ösztönző, rendszeres testmozgás alapú programok is (Hidvégi et al., 2017; Madarász et al., 2019).

Napjainkban megfigyelhető, hogy előtérbe kerülnek a stressz eredetű megbetegedések, ebből kifolyólag a stresszoldó módszerek, eljárások iránti kereslet is fokozatosan növekszik. Egyre népszerübbek azok a szolgáltatások, melyek a stressz-szint csökkentését eredményezik, mint például a szauna, a masszázs vagy a meditáció (Lengyel, 2016). Ezzel párhuzamosan a szabadidősport kínálatban azok a fitnesz mozgásformák is erősen dominálnak, melyeknek jelentős a szerepük a stressz-kezelésében. Ilyen például a jóga, a stretching technikák vagy éppen a horgászat. Az előző tendenciák eredményeként - az egészséges életmód iránti igény térnyerése miatt - megnő a képzett szakemberek (személyi tréner, életmód tanácsadó, stb.) iránti kereslet is, akik segítenek az életmódváltásban és az egészségtudatos életmód kialakításában.

Az új típusú mozgásformák és sportok, valamint a fitnesz keresletének növekedésével egyre több szakirodalom foglalkozik a téma gazdasági hátterével és jelentőségével (Kovács et al., 2016; Sárközy, 2017; Kerezsi et al., 2019; Tarnóczi-Fenyves, 2018; Faragó et al., 2018). A fitneszipar gazdasági jelentősége egyre növekszik. Árbevétel tekintetében az európai egészség és fitnesz piac 1,9\%-os (26,6 millió EUR) növekedést mutatott 2017-ben, mely 2018-ban már 27,2 millió EUR mértékü volt. A piaci növekedés hajtóereje 2017-ben a fitneszklubok számának 3,2\%-os növekedését eredményezte, melyhez átlagosan 0,7\%-os klubtagság is társul klubonként. Mindez 4,0\%-os összlétszám-növekedést jelentett, 60 millió EUR értékben (Deloitte, 2018). Ezek az adatok a Deloitte 2019-es jelentése alapján további pozitív növekedést mutattak. A piaci növekedést elsősorban ismét a klubok számának 4,6\%-os növekedése eredményezte, amely az európai országokban 61 984-re emelkedett. Ezt kísérte a fitnesz klubtagsággal rendelkezők számának (3,5\%-os mértékü) növekedése, amely így 62,2 millió EUR értéket tett ki (Deloitte, 2019). Az előzőek mellett a tagok költéshajlandósága is nőtt: 2017-ben a fitnesz klubtagok átlagosan 38,6 EUR-t, 2018-ban pedig 39,3 EUR-t fizettek havonta a klubtagság nyújtotta fitnesz-szolgáltatásokért.

A fitneszfogyasztók motivációjával, valamint a létesítményválasztást befolyásoló tényezők feltárásával kapcsolatosan is több kutatás foglalkozott napjainkban (Bartha, 2016; Bartha et al. 2018; Bartha - Bácsné, 2018). 


\section{Anyag és módszer}

Kutatásunk célkitűzése volt, hogy megvizsgáljuk, hogy az Észak-alföldi régióban müködő fitnesztermek szolgáltatásai hogyan viszonyulnak napjaink nemzetközi fitnesz trendjeihez. Választ kerestünk arra, hogy a szolgáltatók a sportkínálatukban hogyan jelenítik meg a fogyasztói trendeket, valamint, hogy milyen mozgásformák jelennek meg dominánsan a régióban működő fitnesztermek kínálatában. Kutatómunkánk során - személyes megkereséssel egybekötött - mélyinterjús kutatást végeztünk a régióban működő fitnesztermek körében. Eredményeinket a megkérdezett $33 \mathrm{db}$ terem által adott válaszokat összegezve kaptuk. A mintában szerepelt mindhárom Észak-alföldi régióban elhelyezkedő megyében működő fitneszterem. A strukturált mélyinterjúban kérdéscsoportok kidolgozását követően történt a termek adottságainak, müködési jellemzőinek és célkitűzéseinek felmérése. Jelen munkában a kínálati elemekre, azon belül elsődlegesen az alapszolgáltatásokkal kapcsolatos kérdéskörökre fókuszálunk. A mintában képviselve voltak mind a kisebb városokban, mind a megyeszékhelyeken üzemelö, régebb óta müködő és fiatalabb (1919-estől a 2017-es alapításúig), valamint a néhány fötől a több tíz fös alkalmazotti létszámot foglalkoztató termek.

\section{Eredmények}

$\mathrm{Az}$ 1. ábrán látható módon az általunk vizsgált fitnesz termek 52\%-a egyéni és csoportos órákat is kínál a vendégeknek, a 39\%-uk egyéni edzéslehetőséget ad, melyhez igény esetén személyi edzőt biztosít. A fitnesz szolgáltatók 9\%-a akik csupán csoportos foglalkozásokat biztosítanak a vendégek részére (pl. jóga stúdió). A csoportos edzés igen népszerü napjainkban, hiszen a közösen végzett edzésmunka motiváló hatása igen domináns, mely segíti az egyént az edzéscélok elérésében (Müller-Rácz, 2011).

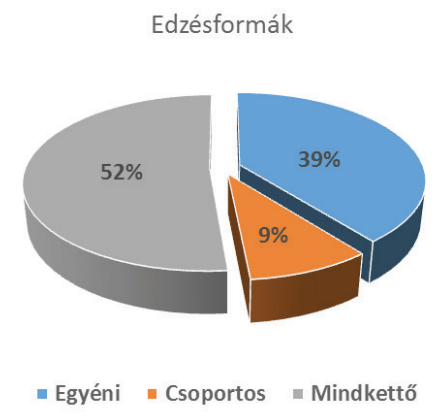

1. ábra: Az edzésformák megoszlása a vizsgált termek esetében Forrás: saját szerkesztés 
Az alábbi, 2. ábrán a vizsgált fitnesztermek esetében leggyakrabban megjelenő edzésformákat szemléltetjük.

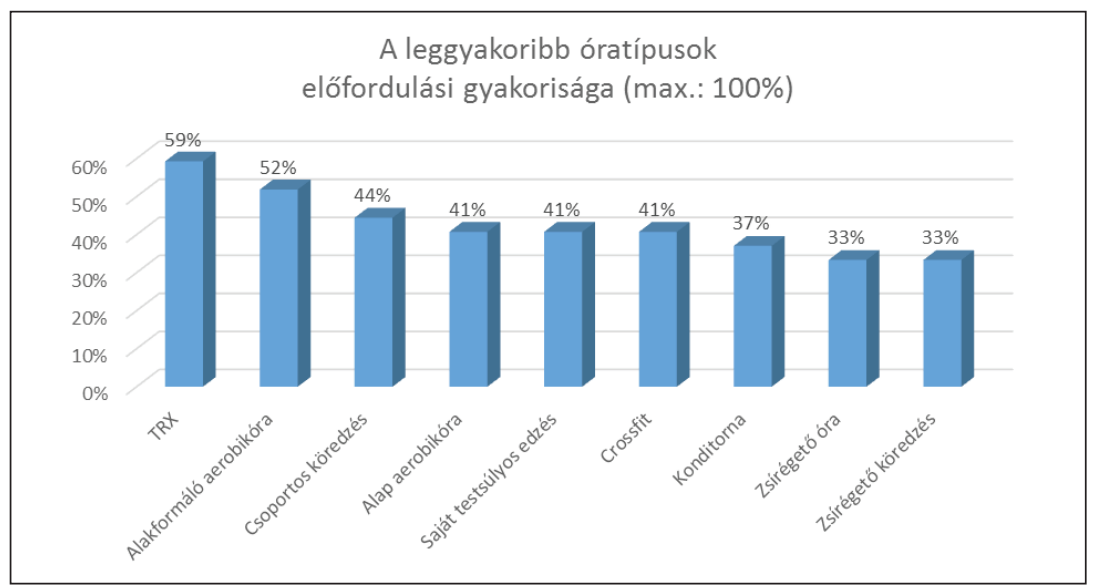

2. ábra: A leggyakrabban megjelenő edzésformák, valamint megjelenésük gyakorisága a vizsgált termek esetében

Forrás: saját szerkesztés

A fitnesztermekben kínált óratípusok közül a TRX óra - amely tulajdonképpen egy felfüggesztéssel történő, saját testsúlyos edzés - az, amelyet a legtöbb szolgáltató kínál. A TRX eszközzel végrehajtott edzésfeladatok alkalmasak arra, hogy fejlesszék az egyén erő-állóképességét, relatív erejét, mely az egyes izomcsoportok izolált vagy együttes fejlesztésével érhető el. Ezek a gyakorlatok a fitnesztrendek között markánsan kapcsolódnak a funkcionális tréninghez, a saját testsúlyos edzésekhez, az erősítő jellegű gyakorlatokhoz, és a magas ismétlésszám miatt alkalmasak a zsírégetésre, testsúlycsökkentésre, a szálkásításra és az alakformálásra is. Ezek a mozgásprogramok 2007 óta erősen tartják magukat a nemzetközi és hazai fitnesztrendek rangsorában (Thompson 2006-2018, Müller et. al. 2017, Gödény et. al. 2018, Molnár 2019). A közelmúltban több kutatás is irányult annak vizsgálatára, hogy a TRX gyakorlatok milyen edzéshatást váltanak ki. Gaedtke - Morat (2015) kiemelte az idősekre gyakorolt pozitív hatást, és javaslatként fogalmazta meg számukra az erősítő és statikus egyensúlyozó gyakorlatok végzését. Fong et al. (2015) pedig arról számolt be, hogy az említett, új típusú mozgásformát a hátfájásban szenvedők esetében alkalmazták sikeresen.

Az alakformáló aerobic óra szintén sok szolgáltató kínálatában megjelenik, hiszen a felmérésben részt vevő termek több mint felének (52\%) kínálatában megtalálható. Emellett az alap aerobic óra is közkedvelt: a szolgáltatók 41\%-a szerepelteti a mozgásprogramok között. Az aerobic kapcsolódik a zenés-táncos mozgásformák, a fogyást 
elősegítő gyakorlatok, a saját testsúllyal végzett erősítő gyakorlatok, valamint a kövérség elleni küzdelemhez kapcsolódó trendekhez (Müller et al., 2019).

A második leggyakrabban megjelenő mozgásformát, a csoportos köredzést a vizsgált szolgáltatók 44\%-a kínálja, mely alkalmas az erő-állóképesség és állóképesség fejlesztésére, a zsírégetésre, továbbá hatékonyan valósítható meg a funkcionális tréning-gyakorlatokkal kombinálva. Ezáltal szintén napjaink fitnesztrendjeibe illeszkedik, hiszen a testsúlycsökkentéshez, az erősítő gyakorlatokhoz és a magas intenzitású gyakorlatok végzését előtérbe helyező programokhoz igazodik. A köredzés már 2013 és 2018 között folyamatosan szerepelt az ACSM (American Colleagues of Sport Medicine) által közzétett TOP 20 fitnesz mozgásformában.

A saját testsúlyos edzést - az alap aerobik órához hasonlóan - a szolgáltatók 41\%-a kínálja. Ahogy korábban ismertettük, a saját testsúllyal végzett gyakorlatok a relatív erőt, és a magas ismétlésszám miatt az erő-állóképességet is fejlesztik. Mint az ACSM trendvizsgálatából kiderül, ez az edzésmódszer 2013-ban és 2014-ben még a második helyen szerepelt a TOP 20-as fitnesztrend listán, míg 2015-ben megszerezte az előkelő első helyet. Ezt követően 2016-ban és 2017-ben ismét a második 2018-ban pedig már a negyedik helyre csúszott vissza (Thompson 2013-2018). Az előzőek alapján elmondható, hogy a saját testsúlyos edzés folyamatosan tartja a helyét a fitnesz edzésmódszerei között.

A crossfit - mely tulajdonképpen funkcionális edzés magas intenzitáson végrehajtva - szintén a termek 41\%-ánál érhető el. Smith et al. (2013) igazolja ennek az edzésmódszernek a kardiovaszkuláris állóképességre és a testösszetételre (testzsírszázalék) kifejtett kedvező hatásait, melyet Bellar és mtsai (2015) is megerősítettek.

A konditorna a szolgáltatók 37\%-ánál megjelenő népszerü óratípus, melynek célja a fittségi szint növelése, valamint az általános kondicionális állapot javítása.

A zsírégető óra és a zsírégető köredzés (33-33\%) egyaránt megjelennek a leggyakoribb óratípusok között. Ezek elsődlegesen a sovány, zsírmentes testtömeg elérését, valamint a fogyást célozzák meg. Népszerüségük azzal is összefüggésben állhat, hogy Magyarország az elhízásban és túlsúlyban szenvedők számában, arányában sajnos vezető helyek egyikén szerepel a világon, ezzel jelentősen növelve az egészségügyi terheket (Iski-Rurik, 2014; Rurik et al., 2016; Müller, 2018).

A legnépszerübb szolgáltatásokon túl - bár kisebb gyakorisággal - a fitnesztermekben megjelentek még olyan egyéb modern mozgásprogramok, mint a jóga, a hot-iron, a zumba, a step aerobic, a bosu és hasonlók. Hozzá kell tenni, hogy a kisebb gyakorisággal megjelenő mozgásformák kínálatba illesztése alkalmas lehet az egyediség elérésére, ezáltal az adott szolgáltatóegység versenytársaktól való megkülönböztetésre.

A legtöbb szolgáltató koedukált termet kínál a vendégeknek, míg csupán a szolgáltatók 30\%-a biztosít külön férfi, illetve női teremrészleget (3. ábra), mely gépekben és felszerelésekben is alkalmazkodik a nemek eltérő adottságaihoz, terhelhetőségeihez és edzéscéljaikhoz. 


\section{Van-e a teremnek külön női és férfi részlege?}

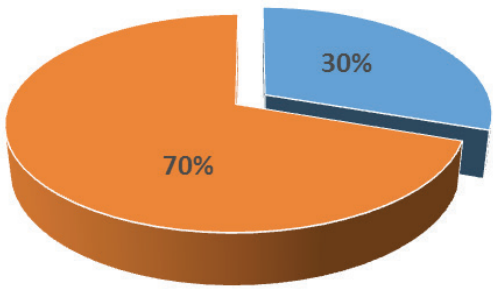

- Van $=$ Nincs

\section{3. ábra: A vizsgált termek jellemzői a nemek tekintetében}

Forrás: saját szerkesztés

Mindez szintén hozzájárulhat az adott egység egyediségének megteremtéséhez, és a versenytársak közül való kitűnést, ezáltal a forgalom növekedését is szolgálhatja.

\section{Következtetések és javaslatok}

A fitneszipar aktuális trendjeinek követése, valamint a folyamatosan változó és formálódó fogyasztói igényekhez alakított kínálat a sport és szabadidős tevékenységek területén működő szolgáltatók számára nélkülözhetetlen versenyképességük megtartása érdekében. A fitneszipar gazdasági szerepe növekszik, Európában dinamikus bővülést mutat, melyet a klubok és klubtagok számának növekedése, a fogyasztók költéshajlandóságának növekedése is generál.

Az Észak-alföldi régióban működő fitneszszolgáltatók tapasztalatai alapján megállapíthatjuk, hogy a hazai fogyasztói igények a nemzetközi fitnesz trendekhez hasonlóan változnak. Ezeket a változásokat a szolgáltatók igyekeznek a kínálatukba minél jobban beépíteni, megjeleníteni.

A funkcionális fitnesz mára egyre népszerübb lett a különböző edzésmódszerek, mozgásformák, aerobic jellegü tréningek között, ezáltal hozzájárulva a fogyasztók fittségi szintjének és teljesítőképességének növeléséhez.

Bár a trendek gyorsan változnak, új mozgásformák, edzéseszközök és módszerek jelennek a fitneszpiacon, az általuk elérendő célok, vagyis az egészségmegőrzés, a fittségi szint növelése, a sovány, zsírmentes és esztétikus külső elérése, a jó közérzet és szórakoztató funkció mégis megmaradnak (Kovács, 2014; Boda et al., 2015; Müller-Bácsné, 2018). 


\section{Köszönetnyilvánítás}

A publikáció elkészítését a “GINOP-2.3.2-15-2016-00062 Életminőség fejlesztése Kelet-Magyarországon: Táplálkozás-, teljesítménybiológiai és biotechnológiai experimentális kutatások és eszközfejlesztések a humán megbetegedések megelőzésére és kezelésére” projekt támogatta.

\section{Hivatkozott források}

[1.] Ács P. - Hécz R. - Paár D. - Stocker M. (2011): A fittség (m)értéke. A fizikai inaktivitás nemzetgazdasági terhei Magyarországon. Közgazdasági Szemle, 58. évf., 7-8. szám. 689-708. o.

[2.] Bartha É. (2016): A fitnesz ipar gazdasági és társadalmi jelentősége. In: Szmodis M. - Szőts G. (szerk.): Sokszínű sporttudomány, Magyar Sporttudományi Társaság, Budapest, 24-35. o. ISBN: 9786155187100.

[3.] Bartha É. J. - Bácsné B. É. (2018): Fogyasztói motivációs vizsgálatok fitnesz szolgáltatást igénybevevők körében. International Journal of Engineering and Management Sciences, 3. évf., 4. szám. 442-453. o.

[4.] Bartha É. J. - Müller A. - Bácsné B. É. (2018): A fitnesz fogyasztók sportlétesítmény-választását befolyásoló legfőbb szempontok alakulása életkor szerint. Selye E-Studies, 9. évf., 1. szám. 4-12. o.

[5.] Bellar, D. - Hatchett, A. - Judge, L. W. - Breaux, M. E. - Marcus, L. (2015): The relationship of aerobic capacity, anaerobic peak power and experience to performance in CrossFit exercise. Biology of Sport, 32. évf. 4. sz. 315. o.

[6.] Boda E. - Honfi L. - Bíró M. - Révész L. - Müller A. (2015): A szabadidő eltöltésének és a rekreációs tevékenységek vizsgálata egri lakosok körében. Acta Academiae Paedagogicae Agriensis Nova Series: Sectio Sport, 42. évf. 49-62. o.

[7.] Borbély A. - Müller A. (2008): A testi-lelki harmónia összefüggései és módszertana. Valóság-Térkép-6. In: Koncz I. (szerk.): PEM tanulmányok, Professzorok az Európai Magyarországért Egyesület, Budapest, 211. o.

[8.] Deloitte (2018): European Health and Fitness market. Report 2018. https:// www2.deloitte.com/content/dam/Deloitte/de/Documents/consumerbusiness/European\%20Health\%20and\%20Fitness\%20Report_2018_extract. pdf (2019.01.27.) 
[9.] Deloitte (2019): European Health and Fitness market. Report 2019. https://www2.deloitte.com/content/dam/Deloitte/es/Documents/acerca-de-deloitte/Deloitte-ES-TMT-European-Health-Fitness-Market-2019. pdf (2019.06.27.)

[10.] Ding, D. - Lawson, K. D. - Kolbe-Alexander, T. L. - Finkelstein, E. A. Katzmarzyk, P. T. - van Mechelen, W. - Pratt, M. - Lancet Physical Activity Series 2 Executive Committee (2016): The economic burden of physical inactivity: a global analysis of major non-communicable diseases. The Lancet. 388. évf. 1311-1324. o.

[11.] Faragó B. - Konczosné Szombathelyi M. - Béki P. (2018): A Világ sportpiacának dinamikusan fejlődő területei a 21. század világgazdasági és világpolitikai folyamataiban. Multidiszciplináris Kihívások Sokszínű Válaszok, 2. évf., 94-125. o.

[12.] Fenyves V. - Tarnóczi T. - Bács Z. (2016): Az Észak-alföldi régió élelmiszer jellegű vegyes bolti kiskereskedelmi tevékenységet végző vállalkozásainak elemzése. Közép-európai Közlemények, 2016/3. 34. sz. 165-183. o.

[13.] Fenyves, V. - Dékán Tamásné Orbán, I. - Könyves, E. - Nagy, A. - Sándor, F. (2014): Economical aspects of thermal and medical tourism. APSTRACT - Applied Studies in Agribusiness and Commerce, 8. évf. 4. sz. 77-84.

[14.] Fong, S. S. - Tam, Y. T. - Macfarlane, D. J. - Ng, S. S. - Bae, Y. H. - Chan, E. W. - Guo, X. (2015): Core muscle activity during TRX suspension exercises with and without kinesiology taping in adults with chronic low back pain: implications for rehabilitation. Evidence-based Complementary and Alternative Medicine, 2015. 6. o.

[15.] Gabnai Z. - Müller A. - Bács Z. - Bácsné Bába É. (2019): A fizikai inaktivitás nemzetgazdasági terhei. Egészségfejlesztés, 60. évf., 1. szám. 20-30. o.

[16.] Gaedtke, A. - Morat, T. (2015): TRX suspension training: A new functional training approach for older adults-development, training control and feasibility. International Journal of Exercise Science, 8. évf. 3. sz. 224. o.

[17.] Gődény N. - Biró M. - Lenténé Puskás A. - Lente L. - Müller A. (2018): A fogyasztói szokások és trendek változásának vizsgálata a fitnesz területén. In: Balogh, László (szerk.): Fókuszban az egészség. Debreceni Egyetem Sporttudományi Koordinációs Intézet, Debrecen, Magyarország. 9-18. o.

[18.] Hidvégi P. - Bíró M. - Müller A. - Váczi P. (2017): Testnevelési program a munkahelyi egészségfejlesztésben. Acta Academiae Paedagogicae Agriensis Nova Series: Sectio Sport, 44. évf., 115-138. o. 
[19.] Iski G. - Rurik, I. (2014): Becslések a túlsúly és az elhízás hazai gazdasági terheiről. Orvosi Hetilap, 155. évf. 35. sz. 1406-1412. o.

[20.] Kerezsi D. - Dajnoki K. - Bácsné Bába É. - Tarnóczi T. - Fenyves V. (2019):A kiegészítő melléklet tájékoztató részének vizsgálata a magyarországi sporttevékenységet végző vállalkozások körében. International Journal of Engineering and Management Sciences, 4. évf., 3. szám. 108-116. o.

[21.] Kovács A. - Paár D. - Welker Zs. - Fürész D. - Elbert G. - Stocker M. - Ács P. (2016): Sportfogyasztási szokások alakulásának aktuális helyzete. Magyar Sporttudományi Szemle, 17. évf., 4. szám. 17-22. o.

[22.] Kovács K. (2014): Boldogító mozgás. A sportolás hatása a partiumi hallgatók szubjektív jóllétére, lelki edzettségére és egészségének önértékelésére. Kapocs, 2. évf. 2-13. o.

[23.] Lengyel A. (2016): Tourism, meditation, sustainability. Apstract - Applied Studies In Agribusiness and Commerce, 10. évf., 1. szám. 81-92. o.

[24.] Lenténé Puskás, A. - Hidvégi, P. - Tatár, A. - Pucsok, J. M. - Biró, M. (2018): Recreational potential of the northern great plain region in Hungary. In: Šimonek, J. -Dobay, B. (szerk.): Sport science in motion: proceedings from the scientific conference. Mozgásban a sporttudomány: válogatott tanulmányok a konferenciáról. Komárno, Szlovákia: Univerzita J. Selyeho. 218-226. o.

[25.] Madarász T. - Dajnoki K. - Fenyves V. - Bácsné Bába É. (2019): Sportolást befolyásoló tényezők feltárása a jövő munkavállalói generációja tekintetében - esettanulmány a DE-GTK hallgatói körében. In: Bácsné Bába É. Müller A. (szerk.): Mozgással az egészségért» A fizikai aktivitás jelentősége a jövő munkavállalóinak egészségmegőrzésében: Nemzetközi Konferencia és Workshop: Válogatott tanulmánykötet, Debreceni Egyetem, Debrecen. 6674. o.

[26.] Molnár A. (2019): Fitnesz trendek az egészség szolgálatában. In: Bácsné Bába É. - Müller A. (szerk.): Mozgással az egészségért. A fizikai aktivitás jelentősége a jövő munkavállalóinak egészségmegőrzésében. Nemzetközi Konferencia és Workshop: Válogatott tanulmánykötet. Debreceni Egyetem, Debrecen, Magyarország. 113-120. o.

[27.] Müller A. - Bácsné Bába É. (2018): Az egészséges életmód és a sport kapcsolata. Létavértes SC '97 Egyesület. Létavértes, Magyarország. 96 o. ISBN 978-615-00-3189-7. 
[28.] Müller A. - Bíró M. - Bodolai M. - Hidvégi P. - Váczi P. - Dávid L. - Szántó Á. (2017): A 2016-os fitnesztrendek helye és szerepe a rekreációban. Acta Academiae Paedagogicae Agriensis Nova Series: Sectio Sport, 44. év. 91-102. o.

[29.] Müller A. - Lengyel A. - Koroknay Zs. - Molnár A. (2019): Népszerü fitnesz mozgásformák. In: Bácsné Bába É. - Müller A. (szerk.): Mozgással az egészségért» A fizikai aktivitás jelentősége a jövő munkavállalóinak egészségmegőrzésében: Nemzetközi Konferencia és Workshop: Válogatott tanulmánykötet, Debreceni Egyetem, Debrecen. 106-112. o.

[30.] Müller A. - Rácz I. (2011): Aerobic és Fitness irányzatok. Budapest, Pécs, Dialóg Campus Kiadó, 277. o.

[31.] Müller A. (2009): A legújabb trendek a sportmarketing és menedzsment területén. In: Magyar Sporttudományi Társaság Sportinnovációs Szakbizottság Évkönyve, Magyar Sporttudományi Társaság Sportinnovációs Szakbizottság, Budapest. 59-63. o.

[32.] Müller, A. (2018): Obesity and overweight in Hungary, focusing on high school students. In: Elena, Bendíková (szerk.): Physical Activity, Health and Prevention III. International Scientific Conference: Conference book. Zilina, Szlovákia : IPV Institute of Education. 6-16. o.

[33.] Pucsok, J. M. - Lenténé Puskás, A. - Biró, M. - Hidvégi, P. - Tatár, A. (2018): The effect of packages on wellness tourism in Eastern Hungary, North Great Plain Region and Romania’s Bihor Region. Geosport for Society, 8. évf. 1. sz. 16-21. o.

[34.] Rurik I. - Ungvári T. - Szidor J. - Torzsa P. - Móczár C. - Jancsó Z. - Sándor J. (2016): Elhízó Magyarország. A túlsúly és az elhízás trendje és prevalenciája Magyarországon, 2015. Orvosi Hetilap, 157. évf. 31. sz. 1248-1255. o.

[35.] Sárközy T. (2017): A sport mint nemzetstratégiai ágazat. Előnyök és hátrányok, hosszú távú kilátások. Polgári Szemle: Gazdasági és Társadalmi Folyóirat, 13. évf. 4-6. szám. 143-159. o.

[36.] Simon I. Á. - Kajtár G. - Herpainé Lakó J. - Müller A. (2018): A fizikai aktivitás és a mentális egészség jelentősége a 60 év fölötti korosztály életében. Képzés és gyakorlat: Training and practice, 16. évf., 1. szám. 25-36. o.

[37.] Simonovits A. (2003): Öregedő népesség, medián választó és a jóléti állam mérete. Közgazdasági Szemle, 50. évf., 10. sz., 835-854. o. 
[38.] Smith, M. M. - Sommer, A. J. - Starkoff, B. E. - Devor, S. T. (2013): Crossfit-based high-intensity power training improves maximal aerobic fitness and body composition. Journal of Strength and Conditioning Research, 27. évf. 11. sz. 3159-3172. o.

[39.] Suti, Z. (2009): Európa az öregedés útján vagy talán a „fiatalodás” lépcsőjén?. Közép-Európai Közlemények, 2. évf., 4-5. sz., 36-43. o.

[40.] Tarnóczi T. - Fenyves V. (2018): Knowledge-based economy - Key issues in the intellectual capital measurement by example of two Hungarian stock exchange companies. SEA: Practical Application of Science, 6. évf., 17. szám. 137-150. o.

[41.] Thompson, W. R. (2006): Worldwide survey reveals fitness trends for 2007. ACSM's Health \& Fitness Journal, 10. évf. 6. sz.. 8-14. o.

[42.] Thompson, W. R. (2007): Worldwide survey reveals fitness trends for 2008. ACSM's Health \& Fitness Journal, 11. évf. 6. sz.. 7-13. o.

[43.] Thompson, W. R. (2008): Worldwide survey reveals fitness trends for 2009. ACSM's Health \& Fitness Journal, 12. évf. 6. sz. 7-14. o.

[44.] Thompson, W. R. (2009): Worldwide survey reveals fitness trends for 2010. ACSM's Health \& Fitness Journal, 13. évf. 6. sz. 9-16. o.

[45.] Thompson, W. R. (2010): Worldwide survey reveals fitness trends for 2011. ACSM's Health \& Fitness Journal, 14. évf. 6. sz. 8-17. o.

[46.] Thompson, W. R. (2011): Worldwide survey reveals fitness trends for 2012. ACSM's Health \& Fitness Journal, 15. évf. 6. sz. 9-18. o.

[47.] Thompson, W. R. (2012): Worldwide survey reveals fitness trends for 2013. ACSM's Health \& Fitness Journal, 16. évf. 6. sz. 8-17. o.

[48.] Thompson, W. R. (2013): Now trending: worldwide survey of fitness trends for 2014. ACSM's Health \& Fitness Journal, 17. évf. 6. sz. 10-20. o.

[49.] Thompson, W. R. (2014): Worldwide survey of fitness trends for 2015: what's driving the market. ACSM's Health \& Fitness Journal, 18. évf. 6. sz. 8-17. o.

[50.] Thompson, W. R. (2015): Worldwide survey of fitness trends for 2016: 10th Anniversary Edition. ACSM's Health \& Fitness Journal, 19. évf. 6. sz. 9-18. o.

[51.] Thompson, W. R. (2016): Worldwide survey of fitness trends for 2017. ACSM's Health \& Fitness Journal, 20. évf. 6. sz. 8-17. o. 
[52.] Thompson, W. R. (2017): Worldwide survey of fitness trends for 2018: the CREP edition. ACSM's Health \& Fitness Journal, 21. évf. 6. sz. 10-19. o.

[53.] Bujdosó Z. - Remenyik B. (2008) A hazai turisták életminőségének a feltérképezése az Észak-Magyarország Régióban In: Dávid L (szerk.) A turizmus szerepe az Észak-Magyarország Régióban I-II Gyöngyös: Károly Róbert Főiskola, pp 40-48 (2008)

\section{Szerzők}

\section{Dr. Müller Anetta}

Egyetemi docens

Debreceni Egyetem, Gazdaságtudományi Kar, Vidékfejlesztés, Turizmusés Sportmenedzsment Intézet muller.anetta@econ.unideb.hu

\section{Dr. Bácsné Prof. Dr. Bába Éva}

Egyetemi tanár

Debreceni Egyetem, Gazdaságtudományi Kar, Vidékfejlesztés, Turizmusés Sportmenedzsment Intézet bacsne.baba.eva@econ.unideb.hu

\section{Gabnai Zoltán}

Tudományos segédmunkatárs

Debreceni Egyetem, Gazdaságtudományi Kar, Gazdálkodástudományi Intézet gabnai.zoltan@econ.unideb.hu

\section{Dr. Pfau Christa}

\section{Adjunktus}

Debreceni Egyetem, Gazdaságtudományi Kar, Vidékfejlesztés, Turizmusés Sportmenedzsment Intézet

\section{Prof. Dr. Pető Károly}

Egyetemi tanár

Debreceni Egyetem, Gazdaságtudományi Kar, Vidékfejlesztés, Turizmusés Sportmenedzsment Intézet 